\title{
Leaching of Copper from Furnace Dust by Pure and Mixed Culture of Thiobacillus ferrooxidans and Thiobacillus thiooxidans
}

\author{
Kee Hang Son, Cheal Gyu Lee, ${ }^{\dagger}$ and Namjun $\mathrm{Cho}^{4+*}$ \\ Cheongiu High School, Cheongin 361-814, Korea \\ ${ }^{\circ}$ Department of Environmental Engineering, Cheongin University, Cheongin 360-764, Korea \\ ${ }^{*}$ Department of Applied Chemical Engineering, Korea University of Technology \& Education, Chonan 330-708, Korea \\ E-mail: numcho@kutac.kr \\ Received Angust 3, 2007
}

\begin{abstract}
The relationship between bacterial adsorption and leaching of copper from copper-containing furnace dust has been investigated in the culture systems of $T$. ferrooxidans (Thiobacilhts ferrooxidans). $T$. thiooxidans (Thiobacilhts thiooxidans) and their mixture. Maximum adsorption amounts of $T$. ferrooxidans and $T$. thiooxidans were $1.39 \times 10^{11}$ cells/g and $1.08 \times 10^{11}$, respectively while maximum adsorption amount of mixed culture was $2.06 \times 10^{11}$ cells/g which is close to the sum of that of each bacterial component. These indicate that the two bacterial species have almost independent preferential adsorption sites on furnace dust except ca. $17 \%$ of competitive sites. I Iowever, the efficiency of leaching was not linearly related to the ratio of adsorption in three different systems even though it was increased in parallel with the bacterial adsorption within the same bacterial system.
\end{abstract}

Key Words : Adsorption, Copper, Leaching, Thiobacillts ferrooxidans, Thiobacillts thiooxidans

\section{Introduction}

Microbial leaching processes are useful to recover precious metals such as copper, gold, and uranium from their ores or to leach out some environmentally hazardous heavy metals. Thiobacillus ferrooxidans and Thiobacilhs thiooxidans are frequently utilized to solubilize $\mathrm{Cu}^{21}$ from copper-containing sulfide ores. ${ }^{14} T$. ferrooxidans is able to oxidize metallic sulfides to sulfate directly via direct attack of substrates or indirectly via oxidation of ferrous ion to ferric ion in solution ${ }^{5-7}$ T. thiooxidans attacks sulfur phase of some of the sulfide ores and oxidizes to sulfate but it can not oxidize ferrous ion to ferric ion. However, it is able to leach insoluble covellite in the presence of iron. ${ }^{8}$

Even though $T$. ferrooxidans and T. thiooxidans differ in their capabilities of adsorptions and in their bioleaching actions, they often naturally occur together in acid mines. Dugan \& Apel reported that naturally occurring mixed cultures containing both of $T$. ferrooxidons and $T$. thiooxidans had shown to be highly effective in the catalysis of pyrite dissolution. ${ }^{9}$ However, Donati et al. reported that the mixed cultures never leached better than the most efficient pure culture in covellite dissolution. ${ }^{10}$ Shrihari et al. reported that the adsorptions of $T$. ferrooxidans cells on substrate played a significant role in leaching of chalcopyrite mineral. ${ }^{11}$ Based on the direct mechanism, bacterial attachment on substrate plays an important role in bioleaching.

In this study we investigated the leaching of copper from a copper-containing furnace dust by pure and mixed cultures of T. ferrooxidans and T. thiooxidams in order to examine the possibility to recover copper. We compared the leaching efficiency of copper by pure cultures of $T$. ferrooxidans and T. thiooxidans with that of their mixed cultures in relation to the bacterial adsorption onto the substrates.

\section{Experimental Section}

Substrates. A furnace metallic waste produced from an industrial Cu-scrap melting process was used as a substrate for bacterial adsorption. The main elements in the furnace dust were analyzed with using atomic absorption spectrophotometer (Varian spectra AA-800, USA) and elemental analysis (Fisions EA 1110 CHNS-O, Italy). It contains C $(24.4 \%), \mathrm{Cu}(9.57 \%), \mathrm{Pb}(8.24 \%), \mathrm{Sn}(6.17 \%), \mathrm{S}(2.55 \%)$, $\mathrm{Cd}(0.37 \%)$ and $\mathrm{Fe}(0.18 \%)$. Other components could be oxide and hydrate forms of compounds and minor elements.

Microorganism. T. ferrooxidans (KCTC 2677) and $T$. thiooxidans (KCTC 2505) were obtained from the Korean Collection for Type Cultures. The culture of T. ferrooxidans was inoculated in an aqueous solution containing $3.0 \mathrm{~g}$ of $\left(\mathrm{NH}_{4}\right)_{2} \mathrm{SO}_{4}, 0.1 \mathrm{~g}$ of $\mathrm{KCl}, 0.5 \mathrm{~g}$ of $\mathrm{K}_{2} \mathrm{HPO}_{4}, 0.5 \mathrm{~g}$ of $\mathrm{MgSO}_{4} \cdot 7 \mathrm{H}_{2} \mathrm{O}, 10.0 \mathrm{mg}$ of $\mathrm{Ca}\left(\mathrm{NO}_{3}\right)_{2}, 1.0 \mathrm{~mL}$ of $5 \mathrm{M} \mathrm{H}_{2} \mathrm{SO}_{4}$ and $44 \mathrm{~g}$ of $\mathrm{FeSO}_{4} \cdot 7 \mathrm{H}_{2} \mathrm{O}$ per liter. An aqueous solution containing $0.1 \mathrm{~g}$ of $\mathrm{NH}_{4} \mathrm{Cl}, 3.0 \mathrm{~g}$ of $\mathrm{K}_{2} \mathrm{HPO}_{4}, 0.1 \mathrm{~g}$ of $\mathrm{MgCl}_{2} \cdot 6 \mathrm{H}_{2} \mathrm{O}, 0.14 \mathrm{~g}$ of $\mathrm{CaCl}_{2} \cdot 2 \mathrm{H}_{2} \mathrm{O}$ and $10 \mathrm{~g}$ of sulfur powder per liter was used for T. thiooxidans.

After bacterial growth had reached the exponential phase, the cultures were centrifuged at $1700 \mathrm{G}$ for $10 \mathrm{~min}$ to remove insoluble ferric compounds from the culture solutions. The T. ferrooxidans and T. thiooxidons supematant were passed through a membrane filter (pore size $0.45 \mu \mathrm{m}$ ) to collect the cells, respectively. Then the cells were washed twice with an aqueous sulfuric acid solution $(\mathrm{pH} 2.0)$ and twice with a fresh medium solution same as growth medium but only devoid of iron for $T$. ferrooxidans and only devoid of sulfur for $T$. thiooxidans, respectively. Then, the $T$. ferrooxidans and $T$. thiooxidons cells were suspended in an iron-free growth medium and a sulfur-free growth medium as described above, respectively. 
Bacterial adsorption. $0.10 \mathrm{~g}$ of substrate, a furnace dust, was incubated with $10 \mathrm{~mL}$ of bacterial suspension $\left(7 \times 10^{7}\right.$. $2 \times 10^{9}$ cells $\left.\mathrm{mL}^{-1}\right)$ in a glass flask under controlled agitation at $200 \mathrm{rpm}$ for $10 \mathrm{~min}$ to reach equilibrium. The number of cells remained free in the supernatant was then determined by direct counting of $0.1 \mathrm{~mm}$ depth and $1 / 400 \mathrm{~mm}^{2}$ area with using a hemocytometer.

Bioleaching. Bioleaching experiments of a coppercontaining furnace dust were carried out in agitated flasks. The experiments were performed in $250 \mathrm{~mL}$ volumetric flasks with $100 \mathrm{~mL}$ of bacteria suspension $\left(1 \times 10^{7}\right.$ cells. $\mathrm{mL}^{-1}$ ) and $10 \%(\mathrm{wt} / \mathrm{v})$ funlace dust. Base on our previous work, bacterial adsorptions of $T$. ferrooxidans and $T$. thiooxidans on the furnace dust were highest at $35^{\circ} \mathrm{C} .{ }^{13}$ Thus, the samples were incubated at $35^{\circ} \mathrm{C}$ and $\mathrm{pH} 2.0$ in a shaker at $200 \mathrm{rpm}$. Small portions of the samples were withdrawn at every $24 \mathrm{hrs}$ from the flasks for analysis. Sterilized blank solutions were employed to determine the metal extraction from fumace dust by acid attack.

\section{Results and Discussion}

Adsorption equilibrium. The adsorption behavior of pure and mixed culture of $T$. ferrooxidans and T. thiooxidans were examined since bacterial attachment to substrates has been considered as an important step in bioleaching processes. In order to obtain a quantitative analysis of bacterial adsorption, the adsorption parameter values were determined using the Langmuir adsorption isothem equation. ${ }^{12}$ The adsorption of bacteria can be described as follows:

$$
X_{A}=K_{A} X_{\text {tn }} X_{L} /\left(1+K_{A} X_{L}\right)
$$

where $X_{A}$ and $X_{A m}$ are the adsorption amount and maximum adsorption amount per unit mass of furnace dust, respec-

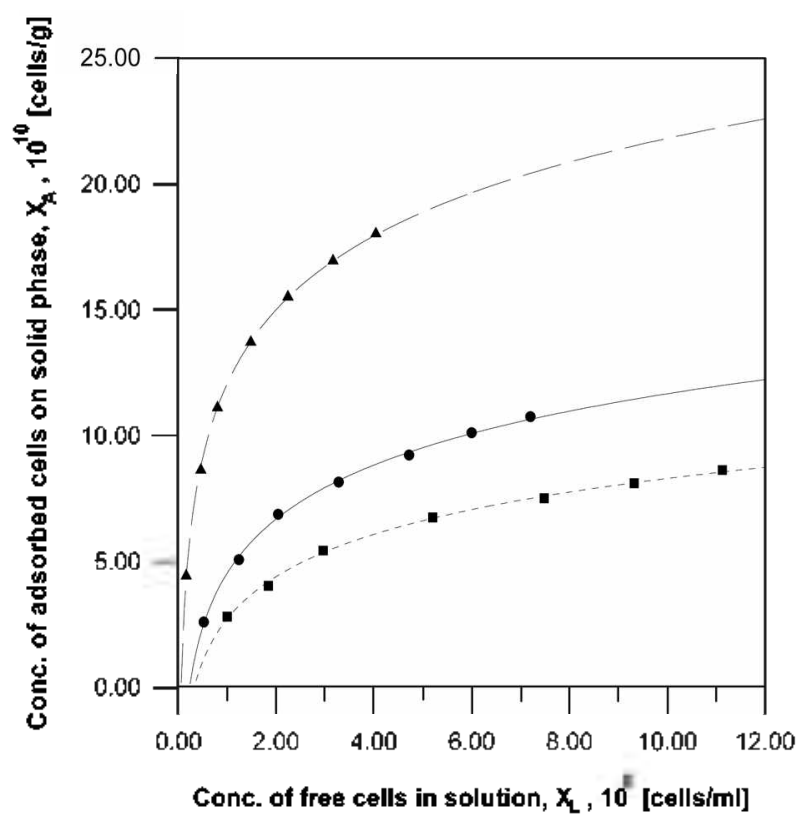

Figure 1. Equilibrium adsorption isotherm of T. thiooxidans ( $\mathbf{\square}$ ), $T$. ferrooxidans $(\bullet)$ and their mixed culture $(\Delta)$ on firnace dust at $35^{\circ} \mathrm{C}$. tively. $X_{L}$ is the concentration of free cells in liquid phase at adsorption equilibrium and $K_{A}$ is the adsorption equilibrium constant. Figure 1 shows the adsorption of $T$. ferrooxidans, T. thiooxidans and the mixed culture of them on furnace dust at $35^{\circ} \mathrm{C}$. We reported in our previous paper that the degree of adsorption of $T$. ferrooxidans, $T$, thiooxidans and their mixed culture increased with increasing temperature from 5 ${ }^{\circ} \mathrm{C}$ up to $35^{\circ} \mathrm{C}$ which was the optimum temperature for growth of these bacteria. ${ }^{13}$ Equation (1) can be rearranged as follows:

$$
X_{L} / X_{A}=X_{L} / X_{A m}+1 / X_{A m} K_{A}
$$

$K_{A}$ and $X_{A m}$ were determined from the plots of $X_{L} / X_{A}$ against $X_{L}$ using a least-square analysis. The plot of $X_{L} / X_{A}$ versus $X_{L}$ resulted in fairly good straight line as shown in Figure 2, which indicates that the adsorptions of $T$. ferrooxidans. $T$. thiooxidans and their mixture on the fumace dust well obey the Langmuir isotherm, as a similar result observed by Konishi et $a .^{14}$ The $K_{A}$ values, an intensive property as a measure of adsorption affinity, were $4.45 \times 10^{-9}$ for $T$. ferrooxidans, $3.30 \times 10^{-9}$ for T. thiooxidans and $14.91 \times 10^{-9}$ $\mathrm{mL} / \mathrm{cell}$ for the mixture. $X_{A m}$ is proportional to the number of adsorption sites per unit surface and the bacteria accessible specific surface area of adsorbent. The $X_{A m}$ values were 1.39 $\times 10^{11}$ for T. ferrooxidans, $1.08 \times 10^{11}$ for T. thiooxidans and $2.06 \times 10^{11} \mathrm{cells} / \mathrm{g}$ for the mixture. The $X_{A t m}$ value of the mixed culture is much larger than that of each pure bacteria, but it is slightly smaller than the sum of that of each bacterial component. These results indicate that the adsorption sites of T. thiooxidans and T. ferrooxidans in funlace dust particles are mostly composed of independent selective sites even though some competitive sites may exist. Berry et al. studied the adsorption of $T$. ferrooxidans to low-grade copper waste ore and reported that $T$. ferrooxidans had preferential

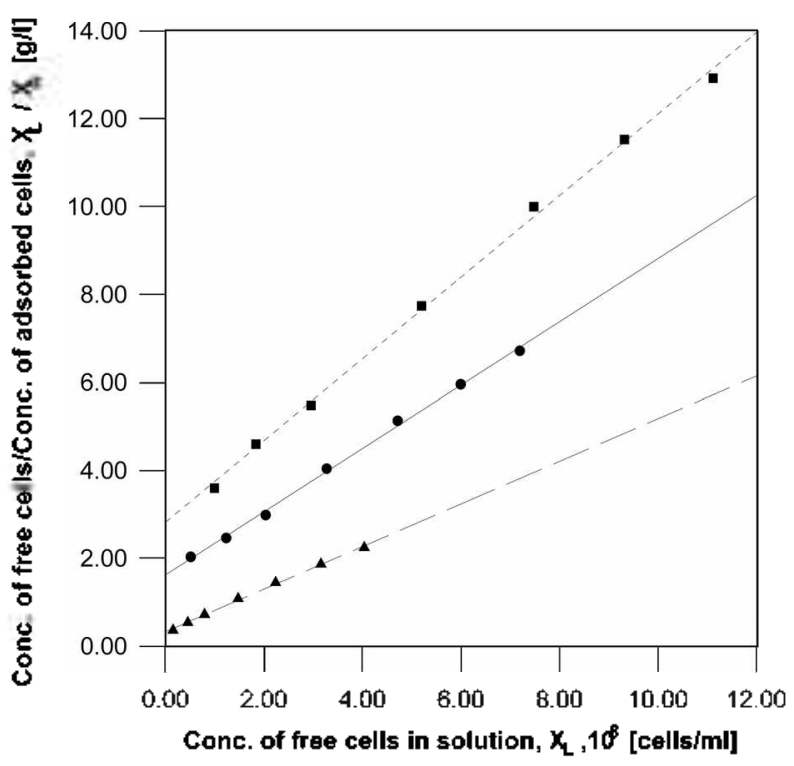

Figure 2. Langmuir plots for the adsorption isotherm of $T$. thiooxidans (ם), T ferrooxidans ( $\bullet$ ) and their mixture (4) on furnace chist at $35^{\circ} \mathrm{C}$. 


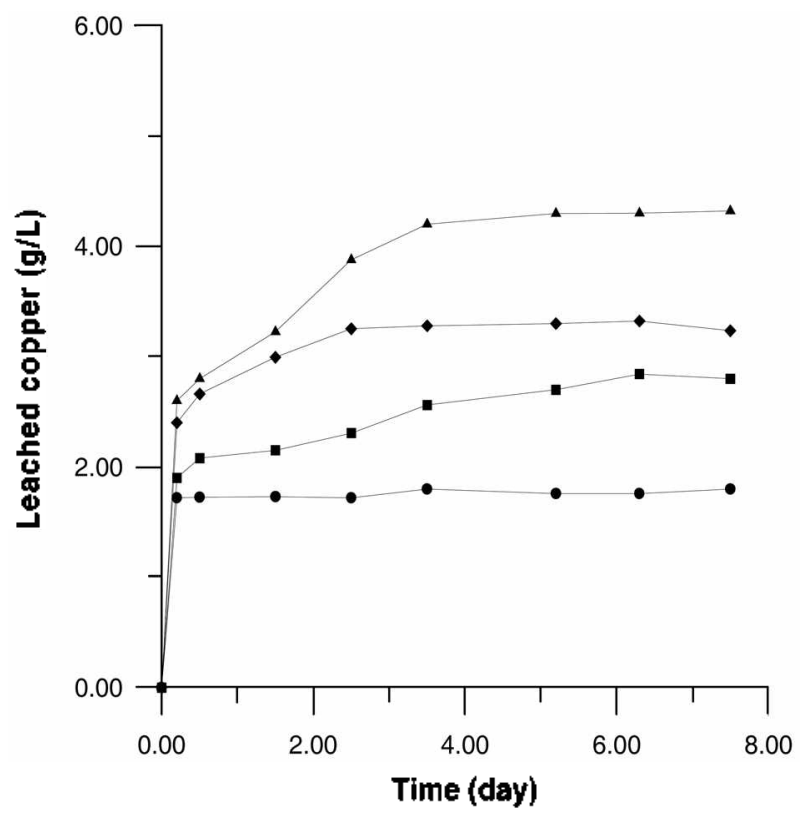

Figure 3. Copper extraction from furnace dust by $T$. thiooxidans $(\boldsymbol{\square})$, T. ferrooxidans $(\bullet)$, mixed culture $(\bullet)$ and sterile system (A). The concentration of copper in solution was analyzed with using atomic absorption spectrophotometer.

\section{adsorption sites..$^{15}$}

Microbial leaching. Figure 3 shows the concentration changes of copper released from a furnace dust by pure culture of $T$. ferrooxidans or $T$. thiooxidans and mixed culture of them. The highest copper extraction was obtained by $T$, ferrooxidans and the lowest by $T$. thiooxidans but somewhat higher than that of sterile system. Curutchet et al. reported that $T$. thiooxidans is able to oxidize soluble sulfides, but it is not able to oxidize insoluble sulfides such as $\mathrm{CuS}$ without iron. ${ }^{8}$ It is consistent with our result that shows small amount of copper released from the relatively insoluble fumace dust by $T$. thiooxidans. However, the copper extraction by $T$. thiooxidans is much larger than that expected from the results of Curutchet $e$ t al., which may caused by small amount of iron $(\mathrm{Fe} / \mathrm{Cu}=1.9 \%)$ contained in the fumace dust that can catalyze the copper leaching by $T$. thiooxidans. ${ }^{8}$ The highest copper extraction by $T$. ferrooxidans may be involved in both of direct copper dissolution by adsorbed $T$. ferrooxidans and of indirect copper oxidation by ferric ions produced by $T$. ferrooxidans oxidation of ferrous ions. Even though the mixed culture showed the highest adsorption, the amount of copper extraction was lower than that by $T$. ferrooxidans but somewhat higher than that by $T$. thiooxidans. It might be caused by the $T$. thlooxidans occupation at some competitive sites that $T$. ferrooxidans can also be adsorbed. Donati $e t$ al. reported similar results that a higher level of covellite dissolution was observed in a system containing $T$. ferrooxidans than that in a system containing mixed culture of $T$. ferrooxidans and $T$. thiooxidans without iron and sulfur. ${ }^{10}$ However, Qiu et al. reported that the bioleaching efficiency of chalcopyrite with $\mathrm{Fe}^{2+}$ and sulfur was higher in mixed culture of $T$. ferro-
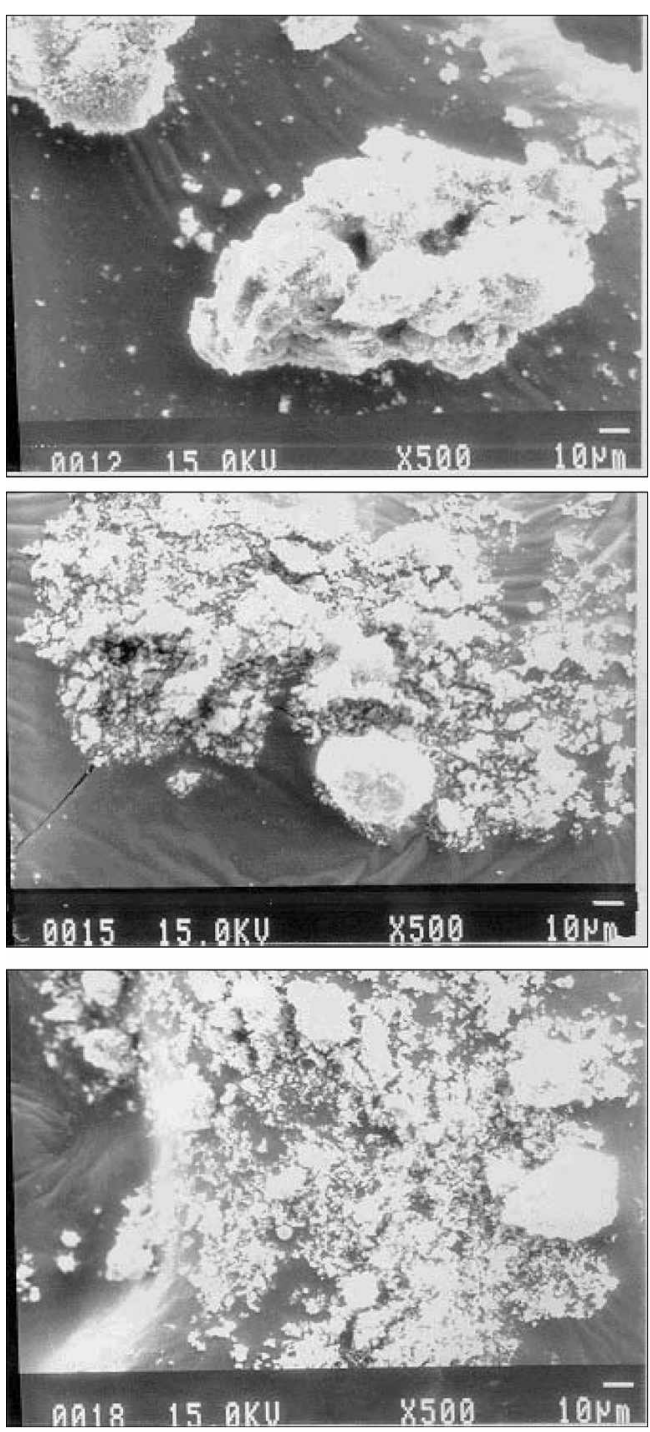

Figure 4. Scanning electron micrographs of furnace dusts at various degrees of bioleaching by mixed culture after $10 \mathrm{~min}$ (top), 3 days (middle) and 7 days (bottom).

oxidoms and T. thiooxidans than in each of their pure culture. ${ }^{16}$ This discrepancy between researchers can be ascribed to the difference of components of their systems such as substrate, pulp density, relative amount of $\mathrm{Fe}^{2+}$ and sulfur, etc.

Figure 4 shows scanning electron micrographs of furnace dust at various degrees of bioleaching by mixed culture after $10 \mathrm{~min}$ (top), 3 days (middle) and 7 days (bottom). As bioleaching is progressed the substrate particles are disintegrated. However, leaching is not much proceeded after 4 days. The relatively fast leaching rate might be partly attributed to the brittleness of the furnace dust. In order to get information of size effect on bacterial adsorption and copper extraction, the substrate particles were sieved into three fractions according to particle size as follows: $\mathrm{A}\left(D_{p}<\right.$ $45 t a m)$, B $\left(45 \mu a \mathrm{~m}<D_{p}<74 \mu \mathrm{m}\right), \mathrm{C}\left(75 t a \mathrm{~m}<D_{p}<149\right.$ $\mathrm{mm}$ ), where $D_{p}$ is the diameter of particle. The $X_{\text {tn }}$ values mixed cultures were $2.06 \times 10^{11}, 1.78 \times 10^{11}$ and $1.58 \times 10^{11}$ 
cells/g for A, B and C, respectively. And the $K_{A}$ values were $14.91 \times 10^{-9}, 8.61 \times 10^{-9}$ and $5.82 \times 10^{-9} \mathrm{~mL} /$ cell for $\mathrm{A}, \mathrm{B}$ and $C$, respectively. As the particle size of furnace dust decreased, the values of $X_{A m}$ and $K_{A}$ increased because of increase in available specific surface area for the bacterial adsorption, and copper extraction also increased parallel with bacterial adsorption.

\section{Conclusions}

A linear relationship between the ratio of adsorption and the efficiency of bioleaching was not observed in three different bacterial culture systems of $T$. ferrooxidans, $T$. thiooxidans and their mixed culture. Maximum adsorption amounts of mixed culture of $T$. ferrooxidans and $T$. thiooxidans was close to the sum of that of each bacterial component. These indicate that the two bacterial species have almost independent preferential adsorption sites on furnace dust except $c a .17 \%$ of competitive sites. However, the efficiency of leaching was not linearly related to the ratio of adsorption in three different systems even though it was increased in parallel with the bacterial adsorption within the same bacterial system. As decreased in substrate particle size, the amount of bacterial adsorption and the apparent rate of copper extraction increased linearly. The amount of copper extraction from furnace dust increased as the adsorption amount increased in the same bacterial system. We concluded that $T$, ferrooxidans was the most efficient in copper leaching from copper-containing furnace dust with no or relatively small amount of iron and sulfur even though the maximum amount of bacterial adsorption was the highest in mixed culture of $T$. ferrooxidans and $T$. thio- oxidans. However, the bioleaching efficiency of copper appears to depend on many components of the systems such as substrate property, pulp density, relative amount of $\mathrm{Fe}^{2+}$ and sulfur, etc. Our future work will focus on the influence of these factors on our system.

\section{References}

1. Torma A. E. Adrances in Biochemical Engineering 1977, 6, 1 .

2. Ingledew, W. J. Biochim. Biophys. Acta 1982, 683,89.

3. Cho, K. S.; Moon, H. S.; Lee, I. S. Korean J. Emviron. Biol. 1999 , $17,183$.

4. Yang, J.-W.; Kim, S.-J.; Park, J.-Y.; Kim, H.-J.; Lee, Y.-J. Korean J. Biotechol. Bioeng. 2002, 17,435.

5. Pono, S.; Ramirez, S.; Reche, C.; Curutchet, G.; Alonso, R. S.; Donati, E. Process Biochem. 1997, 32, 573.

6. Flower, T. A.; Holmes, P. R.; Crundwell, F. K. Applied and Enironmental Mirobiolog: 1999, 65, 2987.

7. Holmes, P. R.; Flower, T. A.; Crundwell, F. K. J. Electrochemical Soc. 1999, 146, 2906.

8. Curutchet, G; Pogliani, C; Donati, E. Biotechnol. Lett. 1995, 17, 1251.

9. Dugan, P. R.; Apel, W. A. In Metallirgical Applications of Bacterial Leaching and Related Microbiological Phenomena; Murr, L. E.; Torma, A. E.; Brierly, J. A., Eds.; Academic Press: New York, 1978; p 223.

10. Donati, E.; Curutchet, G.; Pogliani, C.; Tedesco, P. Process Biocheni. 1996, 31, 129.

11. Shrihari; Kumar, R.; Gandhi, K. S.; Natarajan, K. A. Appl. Microbiol. Biotechnol, 1991, 36, 278.

12. Langmuir, I. J. Am. Chem. Soc. 1916, $38,2221$.

13. Kim, D. W.; Son, K. H.; Jang, Y. H.; Kim, T. S.; Cho, N.; Lee, C. G. J. Biosci. Bioeng. 2000,90, 115.

14. Konishi, Y.; Asai, S.; Noriaki, Y. Appl. Environ. Microbio. 1995. 61,3617 .

15. Berry, V. K.; Murr, L. E. Hy:drometa/hing: 1976, 2, 11 .

16. Qiu, M.; Xiong S.; Zhang W. J. Univ. of Sci. and Tech. Beijing, Mineral, Metallwg; Material 2006, 13, 7 . 